\title{
Technical Note: Quantification of interferences of wet chemical HONO LOPAP measurements under simulated polar conditions
}

\author{
J. Kleffmann and P. Wiesen \\ Physikalische Chemie - Fachbereich C, Bergische Universität Wuppertal, 42097 Wuppertal, Germany \\ Received: 9 January 2008 - Published in Atmos. Chem. Phys. Discuss.: 20 February 2008 \\ Revised: 7 October 2008 - Accepted: 7 October 2008 - Published: 27 November 2008
}

\begin{abstract}
In the present pilot study, an optimized LOPAP instrument (LOng Path Absorption Photometer) for the detection of nitrous acid (HONO) in the atmosphere (DL $0.2 \mathrm{pptV}$ ) was tested at the high alpine research station Jungfraujoch at $3580 \mathrm{~m}$ altitude in the Swiss Alps under conditions comparable to polar regions. HONO concentrations in the range $<0.5-50 \mathrm{pptV}$ with an average of $7.5 \mathrm{pptV}$ were observed at the Jungfraujoch. The diurnal profiles obtained exhibited clear maxima at noon and minima with very low concentration during the night supporting the proposed photochemical production of HONO. In good agreement with recent measurements at the South Pole, it was demonstrated, that interferences of chemical HONO instruments can significantly influence the measurements and lead to considerable overestimations, especially for low pollution level. Accordingly, the active correction of interferences is of paramount importance for the determination of reliable HONO data.
\end{abstract}

\section{Introduction}

Nitrous acid (HONO) is an important source of the $\mathrm{OH}$ radical, the primary oxidant in the atmosphere:

$\mathrm{HONO}+h v(3000-390 \mathrm{~nm}) \rightarrow \mathrm{OH}+\mathrm{NO}$.

While, historically, HONO was considered to make a highly significant contribution to $\mathrm{OH}$ production only in the early morning (Harris et al., 1982; Calvert et al., 1994; Harrison et al., 1996; Volkamer et al., 2007), most recent measurements also indicate a significant contribution to $\mathrm{OH}$ production later during the day (Li, 1994; Neftel et al., 1996; Staffelbach et al., 1997; Zhou et al., 2001; Yang et al., 2002; Vogel et al., 2003; Kleffmann et al., 2005; Acker et al.,

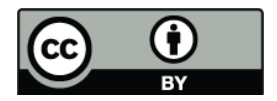

Correspondence to: J. Kleffmann (kleffman@uni-wuppertal.de) 2006a, b), which is explained by photochemical sources (K1effmann, 2007a). In polar regions, unexpectedly high HONO levels have been observed during sunlight over snow surfaces (Li, 1994; Zhou et al., 2001; Beine et al., 2001; Dibb et al., 2002; Honrath et al., 2002; Beine et al., 2002; Dibb et al., 2004; Jacobi et al., 2004; Amoroso et al., 2006). It has been estimated that the photolysis of HONO can be the dominant source of $\mathrm{OH}$ radicals in these regions and that it possibly controls the oxidation capacity of the lower polar atmosphere (Li, 1994; Zhou et al., 2001; Yang et al., 2002). Accordingly, a mechanistic understanding of the production routes for HONO over irradiated snow surfaces and their quantification is of paramount importance for an accurate description of the chemistry in polar regions.

At present, the mechanisms of HONO formation in polar regions are not well understood. It was proposed (Zhou et al., 2001; Beine et al., 2001, 2002; Dibb et al., 2002; Honrath et al., 2002) that HONO formation occurs directly through the photolysis of nitrate on snow surfaces (Dubowski et al., 2002), which can also explain observed $\mathrm{NO}_{\mathrm{x}}$ emissions (for example: Honrath et al., 1999; Cotter et al., 2003; Jacobi et al., 2007). The proposed photolysis of nitrate is based on the observed correlation of the photolytic formation of HONO with the calculated photolysis frequency of nitrate (Honrath et al., 2002) and with the concentration of nitrate in snow (Dibb et al., 2002). However, recent laboratory and accompanying modelling studies imply very low direct photolytic HONO yields and suggest formation of HONO by secondary heterogeneous chemistry, for example via the primary formed $\mathrm{NO}_{2}$ (Jacobi et al., 2007). Such secondary chemistry was also proposed to explain the absence of significant HONO formation from nitrate-containing snow in Antarctic coastal regions, for which, based on the proposed nitrate mechanism, HONO formation should have been observed (Beine et al., 2006). One of the proposed secondary reactions on snow surfaces is the recently observed reduction of $\mathrm{NO}_{2}$ with photo-sensitized organic compounds, for example,

Published by Copernicus Publications on behalf of the European Geosciences Union. 
fulvic and humic acids (George et al., 2005; Stemmler et al., 2006, 2007). The reaction is orders of magnitude faster than the heterogeneous disproportionation of $\mathrm{NO}_{2}$ with water on humid surfaces (Finlayson-Pitts et al., 2003), which was proposed earlier to explain the high HONO yields over snow surfaces (Zhou et al., 2001). The much faster kinetics of this mechanism coupled with the ubiquitous presence of organic compounds in polar regions (Grannas et al., 2004, 2007), suggest that it may help to explain the strong HONO formation and the high $\mathrm{HONO} / \mathrm{NO}_{\mathrm{x}}$ ratios observed in these regions, which cannot be explained by laboratory studies on nitrate photolysis (Zhou et al., 2001; Jacobi et al., 2007). However, verification of this mechanism for polar regions remains an important open issue.

Measurements of gaseous HONO have been made in the atmosphere since the 1980s with various techniques (for example: Platt et al., 1980; Ferm and Sjödin, 1985; Kanda and Taira, 1990; Večeřa and Dasgupta, 1991; Zhou et al., 1999; Heland et al., 2001; Liao et al., 2006). In addition to the only very recently applied spectroscopic LIF (Laser Induced Fluorescence) technique (Liao et al., 2006), only carbonate denuders (Li, 1994; Beine et al., 2001), mist chambers (Dibb et al., 2002; Honrath et al., 2002) and HPLC (High Performance Liquid Chromatography) techniques (Zhou et al., 2001; Beine et al., 2002, 2006) have been used for polar HONO measurements up to now. The common principle of these techniques, herewith termed chemical instruments, is the sampling of HONO on humid or aqueous surfaces followed by analysis in the form of nitrite. However, it is well known that many heterogeneous reactions lead to the formation of nitrite on similar surfaces. One of these reactions, which is typically not considered, is the recently observed fast reduction of $\mathrm{NO}_{2}$ with adsorbed hydrocarbons (Gutzwiller et al., 2002; Kleffmann et al., 2002) during the sampling of HONO. In addition, for polar measurements, interference by $\mathrm{HO}_{2} \mathrm{NO}_{2}$ has been proposed (Liao et al., 2006; Clemitshaw, 2006). Chemical interferences were recently observed and quantified for atmospheric HONO measurements using a LOPAP instrument and the relative interferences were demonstrated to correlate inversely with the pollution level (Kleffmann et al., 2006). Thus, while these interferences may be of particular importance for polar measurements, they are typically not corrected for in measurements performed with chemical instruments. Besides interferences, artificial heterogeneous HONO formation (for example: Kleffmann et al., 1998; Zhou et al., 2002) in sampling lines of up to $30 \mathrm{~m}$ length, used for polar measurements (see for example: Zhou et al., 2001), may affect the accuracy of the data.

These potential problems and results from the modelling of experimental HONO, $\mathrm{NO}_{\mathrm{x}}$ and $\mathrm{HO}_{\mathrm{x}}$ data, have led to the consensus that HONO measurements in polar regions are too high (Chen et al., 2004; Sjostedt et al., 2005; Bloss et al., 2006; Grannas et al., 2007; Sjostedt et al., 2007). This notion has been confirmed recently by the first polar HONO intercomparison study, in which a mist chamber instrument measured HONO values 7 times higher on average than those measured with a LIF instrument (Liao et al., 2006). It is worth mentioning that in other intercomparison studies higher HONO values were also typically measured by chemical instruments compared to the DOAS (Differential Optical Absorption Spectroscopy) technique under rural and urban conditions. This was especially the case during daytime and for low HONO concentrations (Appel et al., 1990; Coe et al., 1997; Müller et al., 1999; Wiesen, 2002; Spindler et al., 2003). Although it is evident that chemical instruments most probably overestimate HONO concentrations in polar regions, data from these types of instruments are still published and used for the interpretation of polar atmospheric processes (Jones et al., 2007).

In conclusion, in order to obtain a better understanding of the impact of HONO on the oxidation capacity of the polar atmosphere there is an urgent need for the exact quantification of HONO concentrations in polar regions by instruments free of interferences and sampling artefacts. Thus, the aim of the pilot study presented here was to demonstrate that the recently developed LOPAP instrument for the detection of HONO in the atmosphere is also capable of working accurately and reliably under polar atmospheric conditions. In addition, quantification of interferences should demonstrate the potential problems of chemical HONO measurements, especially for low pollution levels, if not actively corrected. To simulate polar atmospheric conditions, HONO measurements were performed on the easy accessible high alpine research station Jungfraujoch during the period 2-7 November 2005.

\section{Experimental}

\subsection{LOPAP instrument}

Nitrous acid (HONO) was measured with a very sensitive instrument (LOPAP), which is described in detail elsewhere (Heland et al., 2001; Kleffmann et al., 2002). In addition, most recent modifications are specified in an intercomparison paper (Kleffmann et al., 2006). Briefly, HONO is first sampled in a temperature controlled $\left(20^{\circ} \mathrm{C}\right)$ double-wall stripping coil by chemical reaction in the stripping reagent, which is a mixture of sulphanilamide in hydrochloric acid $(10 \mathrm{~g} / \mathrm{L}$, $1 \mathrm{~N})$. Due to the very fast chemical reaction, only a very short stripping coil $(17 \mathrm{~cm}$ length, $2 \mathrm{~mm}$ i.d.) is required to obtain a $99.4 \%$ uptake for the $1.5 \mathrm{~L} / \mathrm{min}$ gas flow used in the present study. These conditions result in a contact time of only $\sim 30 \mathrm{~ms}$ for interfering substances with the liquid surface. The reactive uptake of HONO in the stripping coil is even faster than the uptake of $\mathrm{HNO}_{3}$ on water, which is why a longer coil $(43 \mathrm{~cm})$ has to be used for a $\mathrm{HNO}_{3}-\mathrm{LOPAP}$ instrument operating under similar conditions (Kleffmann et al., 2007b). The sampling conditions used for the LOPAP instrument also have the advantage that HONO is completely 
sampled at low $\mathrm{pH}$, for which several known chemical interferences caused by, e.g. $\mathrm{NO}_{2}$ and $\mathrm{SO}_{2}$ (Littlejohn et al., 1993; Spindler et al., 2003), $\mathrm{NO}_{2}$ and phenols (e.g. Alfassi et al., 1986; Coombes et al., 1994; Ammann et al., 2005), $\mathrm{NO}_{2}$ +aromatic amines (Saltzman, 1954) or PAN hydrolysis (Frenzel et al., 2000) are minimised (Heland et al., 2001; Kleffmann et al., 2002, 2006).

The stripping coil is mounted in an external temperature controlled sampling unit, which is placed directly in the atmosphere of interest, which avoids the use of any sampling lines. Thus, sampling artefacts in sampling lines, i.e. heterogeneous formation on surfaces by different $\mathrm{NO}_{2}$ reactions (e.g. Gutzwiller et al., 2002; Finlayson-Pitts et al., 2003; Ammann et al., 2005), photolytic formation on surfaces (Zhou et al., 2002), or condensation of analytes on inlet surfaces (Keene et al., 2006) are minimised. After the separation from the gas phase, the stripping reagent is pumped through an isolated temperature controlled reagent line to the instrument, where it is converted into an intensively coloured azo dye by the reaction with N-naphtylethylendiamine-dihydrochloride (Grasshoff et al., 1983). The absorption of the light from a white light-emitting diode (LUXEON) by the dye is measured in long path absorption tubes made of Teflon AF 2400 using a mini-spectrometer (Ocean Optics, SD 2000). The light from and to the absorption tubes is transferred by glass fibre optics $(200 \mu \mathrm{m})$. All continuous liquid flows are adjusted by a peristaltic pump (Ismatec). The light spectra are stored and processed by a mini computer and the absorbance can be continuously followed on the computer.

In the external sampling unit two similar stripping coils are connected in series to correct for interferences, which are expected for chemical HONO instruments (Appel et al., 1990; Spindler et al., 2003; Liao et al., 2006). In the first stripping coil HONO is almost quantitatively sampled (see above). Thus, the signal in the second channel results only from interfering substances, such as $\mathrm{NO}_{2}$. Under the assumption that the interfering substances are taken up only to a small, identical extent in each coil, the difference between the signals in channel 1 and 2 gives the interference free HONO signal. Using this two channel approach, tests for interferences from $\mathrm{NO}, \mathrm{NO}_{2}, \mathrm{NO}+\mathrm{NO}_{2}, \mathrm{~N}_{2} \mathrm{O}_{5}, \mathrm{HNO}_{3}, \mathrm{HNO}_{3}+\mathrm{HCHO}, \mathrm{O}_{3}$, $\mathrm{O}_{3}+\mathrm{HONO}, \mathrm{H}_{2} \mathrm{O}_{2}, \mathrm{H}_{2} \mathrm{O}_{2}+\mathrm{HONO}, \mathrm{SO}_{2}, \mathrm{SO}_{2}+\mathrm{NO}_{2}$, PAN, alkylnitrates, phenols $+\mathrm{NO}_{2}, \mathrm{NO}_{2}+$ diesel exhaust, complex photosmog mixtures and sub-micron particles showed that they are either not measurable or can be corrected for (Heland et al., 2001; Kleffmann et al., 2002; Bröske et al., 2003; Kleffmann et al., 2006). This has also been confirmed by recent intercomparison campaigns in which this instrument was compared with the DOAS technique in the field and in a large outdoor simulation chamber. Excellent agreement was obtained between both techniques for the same air masses and also for daytime conditions. Even though interferences were often significant, the measurement principle allowed the extent of the interferences to be accurately compensated in the measurements (Kleffmann et al., 2006).

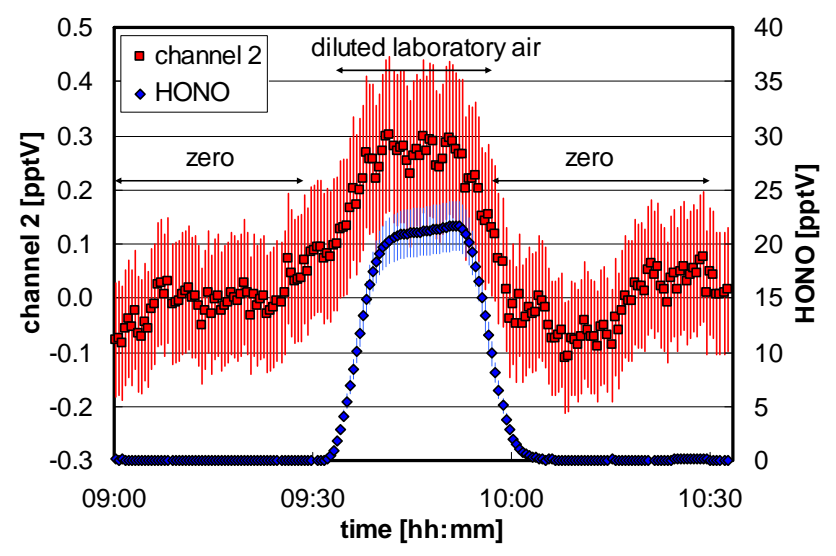

Fig. 1. Sensitivity tests of the optimized LOPAP instrument in the laboratory. For details see text.

To correct for small zero drifts, regular automatic zero measurements of $20 \mathrm{~min}$ every $4 \mathrm{~h}$ were performed during the campaign. To avoid significant "extra" surfaces in the inlet, the zero air was injected directly into the inlet of the stripping coil through a 1/16" PFA line with a slightly higher flow rate than that of the instrument. The instrument was calibrated two times, at the beginning and at the end of the campaign, to ensure constant sensitivity $( \pm 5 \%)$. With an optical path length of $6 \mathrm{~m}$ used in this study the instrument has a detection limit of $0.2 \mathrm{pptV}$ for a response time of $7 \mathrm{~min}$ (10-90\% of final signal); see Fig. 1. Since HONO concentrations near the detection limit cannot be easily generated by a HONO source, the signal of channel 2 of the instrument is also shown in Fig. 1 during the addition of $\sim 20 \mathrm{pptV}$ of HONO. The data in channel 2 reflect chemical interferences and HONO, which are not sampled in channel 1. Since in the atmosphere HONO is determined from the difference of the two channels, a detection limit of $0.2 \mathrm{pptV}$ can be derived from the data shown for channel 2, which is in excellent agreement with the $2 \sigma$ noise of zero measurements during the field campaign at the Jungfraujoch. The accuracy and precision of the instrument are 7\% (+DL) and 1\% (+DL), respectively.

\subsection{Location and weather conditions}

The high altitude research station Jungfraujoch $\left(7^{\circ} 59^{\prime} 2^{\prime \prime} \mathrm{E}\right.$, $46^{\circ} 32^{\prime} 53^{\prime \prime} \mathrm{N}, 3580 \mathrm{~m}$ altitude), which is a Global Atmosphere Watch (GAW) station, is located between the "Jungfrau" and "Mönch" mountains in Switzerland. Measurements were performed at the "Sphinx" building, which is surrounded by large snow and ice fields. Although the station is located in central Europe, recent $\mathrm{NO}_{\mathrm{y}}$ measurements have shown that the air reaching the station is often comparable in composition to air at remote stations (Zellweger et al., 2003). The large snow and ice fields, the temperature range during the campaign and the low pollution level render the 


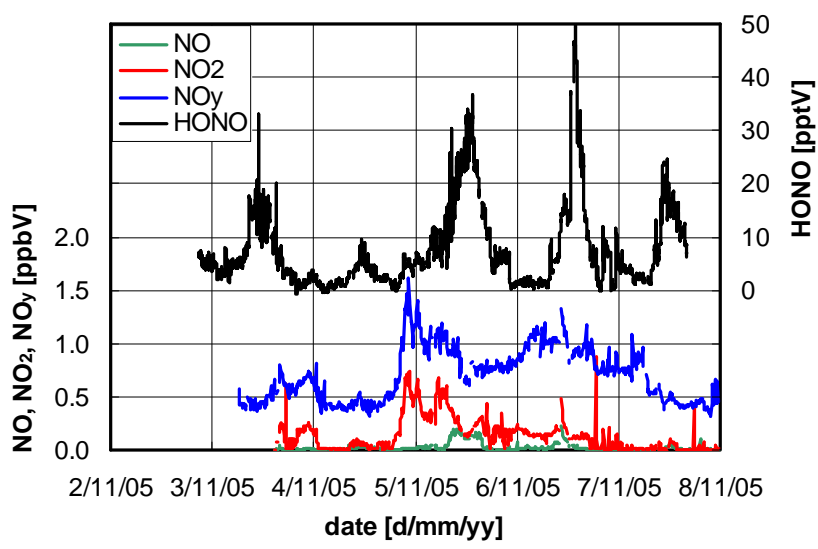

Fig. 2. $\mathrm{HONO}, \mathrm{NO}, \mathrm{NO}_{2}$ and $\mathrm{NO}_{\mathrm{y}}$ concentrations during the field campaign at the Jungfraujoch (2-7 November 2005).

Jungfraujoch an ideal test site for polar measurements; it is also more readily accessible. In particular, during three days of the campaign, when south-easterly winds prevailed, the air flow was coming from the large glacier "Aletschgletscher" directly to the sampling port of the LOPAP instrument and, thus, was in contact with large ice surfaces and not influenced by possible local emissions from the station.

The LOPAP instrument was installed in the GAW laboratory room below the roof of the "Sphinx" building. The external sampling unit was fixed on a plate ca. $1 \mathrm{~m}$ in front of a window on the east-north-east side of the building, ca. $8 \mathrm{~m}$ above the visitor's platform. For three days the sampling unit was upwind and for two days it was downwind of the building. Since no significant difference in the $\mathrm{HONO} / \mathrm{NO}_{\mathrm{y}}$ ratio could be observed between these two periods, artificial heterogeneous formation on surfaces of the building was considered to be of minor importance.

During the campaign the weather conditions varied significantly and included clear skies, snowfall and the presence of super-saturated cloud droplets leading to strong frost needle formation on all surfaces. The temperature varied between -9.2 and $+0.9^{\circ} \mathrm{C}$, the wind speed between $0-15 \mathrm{~m} / \mathrm{s}$ and the pressure between 657-664 mbar.

\section{Results and discussion}

\subsection{Experimental field data}

The HONO concentration varied between $<0.5-50 \mathrm{pptV}$ (see Fig. 2) with a mean value of $7.5 \mathrm{pptV}$, which is similar to the range of concentrations measured in polar regions $(\mathrm{Li}, 1994$; Zhou et al., 2001; Beine et al., 2001, 2002; Dibb et al., 2002; Honrath et al., 2002) and also at other high altitude mountain sites (Kleffmann et al., 2002; Huang et al., 2002; Beine et al., 2005). The measured $\mathrm{NO}, \mathrm{NO}_{2}$ and $\mathrm{NO}_{\mathrm{y}}$ concentra-

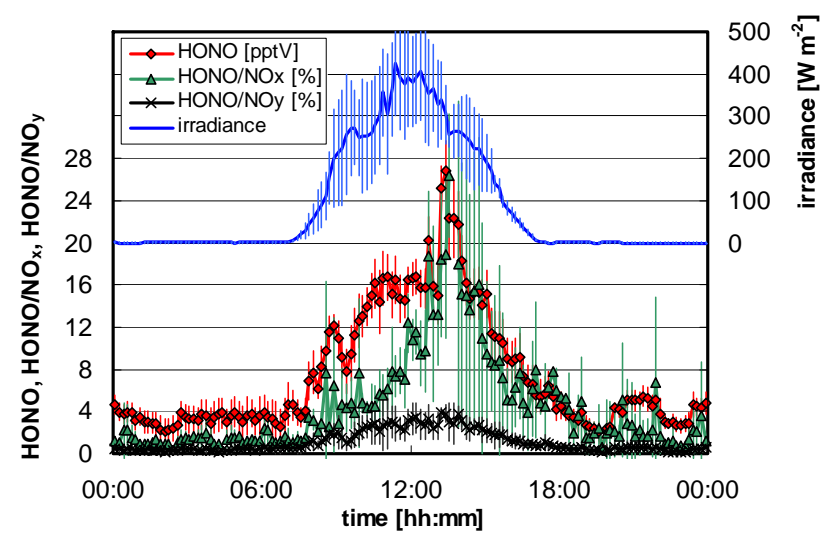

Fig. 3. Mean diurnal $\mathrm{HONO}$ concentration, $\mathrm{HONO} / \mathrm{NO}_{\mathrm{x}}$, $\mathrm{HONO} / \mathrm{NO}_{\mathrm{y}}$ and irradiance (10 min averages) during the field campaign at the Jungfraujoch.

tions were in the range $0-0.22 \mathrm{ppbV}, 0-0.75 \mathrm{ppbV}$ and $0.3-$ $1.6 \mathrm{ppbV}$, respectively (see Fig. 2).

The HONO concentration showed a strong diurnal variation with the highest concentrations occurring during daytime and correlated strongly with the irradiance (see Fig. 3). This observation is in good agreement with other measurements on mountain sites (Kleffmann et al., 2002; Huang et al., 2002; Acker et al., 2006a; Zhou et al., 2007) and also in polar regions and is explained by photochemical HONO sources. For all data an average diurnal HONO profile was calculated from the 10 min mean values of the instrument (see Fig. 3). Average night-time (06:00-18:00) and noon time (12:00-13:00) HONO concentrations of $\sim 3.5 \mathrm{pptV}$ and $\sim 17 \mathrm{pptV}$ were observed. The variability of the data is lower during the night compared to the day. This might be explained by a decrease in the boundary layer height during the night and a much lower influence of the variable pollution from the valleys around the measurement site, in addition to the absence of local photochemical sources. Accordingly, the mean night-time concentration of $3.5 \mathrm{pptV}$ is considered as the upper limit HONO concentration in the free troposphere during night in mid Europe. The high daytime concentrations are most probably caused by fast photolytic formation of HONO, since the diurnal HONO profile nicely matches with the variation of the irradiation (Fig. 3). However, since photolytic HONO formation by heterogeneous processes on ground surfaces is proposed and the lifetime of HONO during the day is only $\sim 10 \mathrm{~min}$, it should be pointed out that these high values are not representative for the free troposphere during the day.

The mean diurnal $\mathrm{HONO} / \mathrm{NO}_{\mathrm{x}}$ and $\mathrm{HONO} / \mathrm{NO}_{\mathrm{y}}$ ratios varied between $0.5-26 \%$ (mean: $4.6 \%$ ) and $0.2-4 \%$ (mean: 1.1\%), respectively, with the low values occurring during nighttime and the high values around noon (see Fig. 3). These values are in good agreement with mean values of $\mathrm{HONO} / \mathrm{NO}_{\mathrm{x}}=2.5 \%$ and $\mathrm{HONO} / \mathrm{NO}_{\mathrm{y}}=1.0 \%$, 
respectively, measured with a LOPAP instrument at the high altitude mountain site Zugspitze ( $2650 \mathrm{~m}$ altitude, unpublished data from Kleffmann et al. (2002)). However, the mean $\mathrm{HONO} / \mathrm{NO}_{\mathrm{x}}$ ratio determined with the LOPAP instrument is much lower than those determined in other field campaigns on high mountain sites using other chemical instruments, for which mean values of $\sim 30 \%$ (Huang et al., 2002) and 23\% (Zhou et al., 2007) were reported. In addition, during polar field campaigns very high ambient $\mathrm{HONO} / \mathrm{NO}_{\mathrm{x}}$ ratios of $\sim 25 \%$ (Beine et al., 2001; Jacobi et al., 2004) up to $\sim 100 \%$ (Jones et al., 2007) have been determined. These high values may be explained by significant chemical interferences, which are not normally corrected for in other chemical instruments (see below).

The average diurnal HONO concentration was highly correlated with the irradiance $\left(R^{2}=0.83\right)$ and the product (irradiance $\times 1 /$ wind speed) $\left(R^{2}=0.88\right)$, consistent with the proposed photochemical formation on ground surfaces. In addition, HONO was moderately correlated with NO $\left(R^{2}=0.58\right)$. However, no positive correlation of HONO with $\mathrm{NO}_{2}, \mathrm{NO}_{\mathrm{y}}$ or $\mathrm{NO}_{\mathrm{z}}$ was observed. Accordingly, based on the experimental observations, the mechanism of the photolytic daytime HONO formation, i.e. nitrate photolysis (Zhou et al., 2001; Beine et al., 2001, 2002; Dibb et al., 2002; Honrath et al., 2002) versus photo-sensitized $\mathrm{NO}_{2}$ reduction on organic surfaces (George et al., 2005; Stemmler et al., 2006, 2007), still remains an important open question. However, clarification of this question was not the objective of this pilot study.

\section{Interferences}

In the LOPAP instrument two channels are used to correct for interferences. While HONO is almost completely taken up by a very fast selective chemical reaction in the first channel, other tested interfering gases pass the first coil nearly unaffected (see above). This can be explained by a saturation of a thin surface layer of the sampling reagent and a liquid phase diffusion limited uptake of interfering gases, which is driven by their solubility. In contrast, due to the extremely high excess of the reactant sulfanilamide $(10 \mathrm{~g} / \mathrm{L})$, each colliding HONO is taken up by a chemical reaction in the sampling solution of the LOPAP instrument. Thus, it is proposed, and confirmed for all tested interferences in the laboratory (see above), that the interference signal is similar in both channels. Accordingly, the difference channel 1-channel 2, corrected for the small fraction of HONO that passes through the first channel, gives the interference free HONO concentration. This is confirmed by the excellent agreement between the measurements made with the LOPAP and DOAS instruments under complex conditions in the atmosphere and in a smog chamber (Kleffmann et al., 2006). It should be pointed out, that interferences are also expected to be of importance for other chemical instruments, since they typically have longer gas/liquid contact times in their sam- pling devices compared to the LOPAP instrument ( $\sim 30 \mathrm{~ms})$. For example, the recently observed interfering compounds from diesel exhaust were found to be completely removed by a wetted effluent diffusion denuder (WEDD) (Gutzwiller et al., 2002), while only a small, correctable uptake was observed for the LOPAP instrument (Kleffmann et al., 2002). In addition, since the kinetics of most known interfering liquid phase reactions, i.e. PAN hydrolysis (Frenzel et al., 2000), $\mathrm{NO}_{2}+\mathrm{SO}_{2}$ (Littlejohn et al., 1993; Spindler et al., 2003), $\mathrm{NO}_{2}+$ phenols (Alfassi et al., 1986; Coombes et al., 1994; Ammann et al., 2005) or $\mathrm{NO}_{2}+$ aromatic amines (Saltzman, 1954), increase with increasing $\mathrm{pH}$, these chemical interferences are expected to be even more severe for instruments that collect air samples under neutral or even basic conditions (see for example, Spindler et al., 2003; Genfa et al., 2003). In contrast, in the LOPAP instrument very acidic sampling conditions are applied $(\mathrm{pH}=0)$.

Most of the available intercomparison studies support that interferences are a general problem associated with chemical instruments (Appel et al., 1990; Coe et al., 1997; Müller et al., 1999; Spindler et al., 2003; Wiesen, 2002; Liao et al., 2006), since the chemical instruments typically measure significantly higher concentrations than the spectroscopic instruments, especially during daytime and for low HONO concentrations. The differences are attributed to the occurrence of interferences in the chemical instruments (e.g. Appel et al., 1990; Spindler et al., 2003; Liao et al., 2006). However, there are two intercomparison studies, for which good agreement has been reported between the measurements made with the DOAS technique and those made with chemical instruments, where no corrections for interferences were applied (Acker et al., 2006b; Keene et al., 2006). In the study of Keene et al. (2006) in which a mist chamber (MC) instrument was compared with a DOAS instrument a slope MC/DOAS of 1.2 and an intercept for the MC (DOAS=0) of $49 \mathrm{pptV}$ was determined. If this correlation analysis is statistically significant, this would result in much higher $\mathrm{HONO}$ concentrations from the MC at very low HONO levels (polar conditions) and better agreement at high HONO levels. This would be consistent with other existing intercomparison studies (Appel et al., 1990; Müller et al., 1999; Spindler et al., 2003) and the anti-correlation of the relative interferences of the LOPAP instrument with the HONO concentration (see below). However, half of the data points were below the detection limit of the DOAS in the study of Keene et al. (2006). In addition, since the performance characteristics of the MC-IC technique for HONO were not rigorously characterized (for details see Keene et al., 2006), the HONO data were considered as being semi-quantitative in nature by the authors (Keene et al., 2006). Thus, the reported data should not be used to argue that HONO measurements using chemical instruments are not affected by interferences.

In another recent study (Acker et al., 2006b) good agreement was reported between an HPLC, a WEDD (Wetted Effluent Diffusion Denuder) and a DOAS system for field 


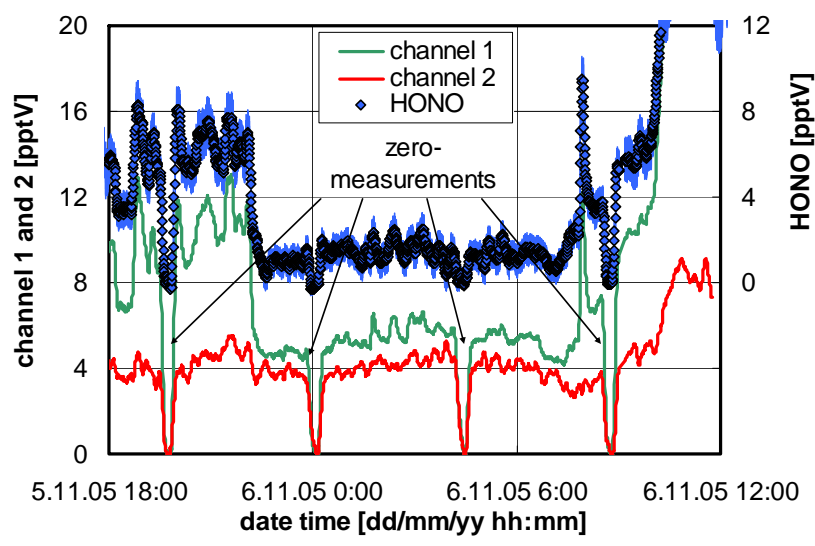

Fig. 4. Example of high interferences observed in the night 5-6 November 2005, leading to an overestimation of the HONO concentration of up to a factor of 4 , if only a one channel instrument would be used.

measurements in Rome, made as part of the European NITROCAT project. However, when the data presented in the final report of the project (Wiesen et al., 2002) are examined in detail, for 11 of 17 simultaneous days the HPLC system measured significantly higher HONO values (up to a factor of 4) than the DOAS instrument during daytime, while the night-time values were on average in good agreement. The high daytime HONO concentrations occurring during the campaign were almost always above the detection limit of the instrument and thus the deviation with the HPLC system is statistically significant for low HONO concentrations. This is also confirmed by a regression analysis of all the simultaneous HPLC data against the DOAS data which leads to a slope of $(0.92 \pm 0.03)$ and an intercept of $(0.20 \pm 0.03)$. Similar observations with good agreement at high HONO levels but significant overestimation by the chemical instruments compared to the DOAS technique for low HONO values has been reported in other intercomparison studies (Appel et al., 1990; Müller et al., 1999; Spindler et al., 2003). In conclusion, the significantly higher daytime values of the HPLC instrument compared to the DOAS technique for the NITROCAT campaign, and similar observations from other intercomparison studies (see above), confirm the general importance of chemical interferences.

In the present study the measured interferences of the LOPAP instrument were examined in more detail to quantify the magnitude of the correction for simulated polar conditions and to gain deeper insight into the chemical processes responsible for the interferences.

While, typically, the correction of interferences was in the range $10-50 \%$ for the campaign at the Jungfraujoch, very high relative interferences of $>100 \%$ were observed several times during the campaign (see Fig. 4 and Fig. 5). For the data shown in Fig. 4 the signal of the interference channel 2 was nearly as high as that of channel 1 . The reason for

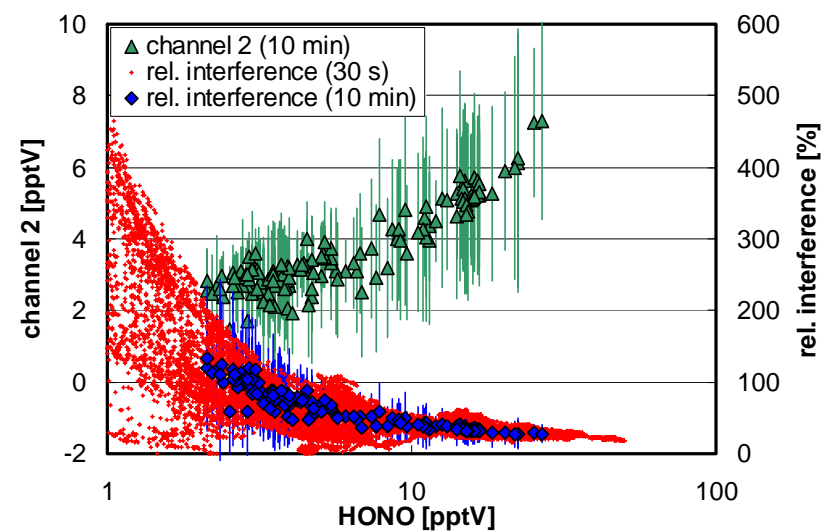

Fig. 5. Absolute interferences (channel 2) and relative interferences as a function of the HONO concentration for all data and for the average diurnal $10 \mathrm{~min}$ data during the campaign at the Jungfraujoch.

these surprisingly high interferences is still unclear. The small and well-known interferences of the LOPAP instrument, for example due to ozone and $\mathrm{NO}_{2}$ (Kleffmann et al., 2002), can only explain a signal of $\sim 1 \mathrm{pptV}$ in channel 2 under the conditions shown in Fig. 4. In addition, there was no correlation of the interference signal with the concentration of $\mathrm{O}_{3}\left(R^{2}=0.009\right), \mathrm{NO}_{2}\left(R^{2}=0.15\right.$, slope negative $)$ and $\mathrm{NO}_{\mathrm{y}}\left(R^{2}=0.27\right.$, slope negative $)$. Thus, other unknown interferences such as, for example, oxidizable hydrocarbons (Alfassi et al., 1986; Coombes et al., 1994; Gutzwiller et al., 2002; Ammann et al., 2005), might explain the observed high signal in channel 2 . The relative interference was found to increase with decreasing HONO-concentration (see Fig. 5), which is in excellent agreement with observations from other field campaigns in which the LOPAP instrument was used (Kleffmann et al., 2006). This indicates that especially for remote conditions the correction of interferences is of paramount importance for the correct determination of HONO concentrations by the LOPAP technique.

A significant correlation of the measured interference signal of channel 2 with the irradiance was also observed (see Fig. $6, R^{2}=0.79$ ). This might be explained by the photochemical formation of interfering compounds, such as phenols, during daytime. In addition, it might also reflect the micrometeorological variations associated with surface heating by solar radiation, which could cause stronger upward transport of air masses containing higher concentrations of interfering compounds.

The results from the present study demonstrate the importance of using a two channel chemical LOPAP instrument for the detection of nitrous acid in the atmosphere. For example, as can be seen in Fig. 4, the HONO concentration would have been overestimated by a factor of up to 4 if only a one-channel LOPAP instrument had been used. This factor can be compared with the observed mean discrepancy of a factor of 7 between data from a one channel mist chamber 


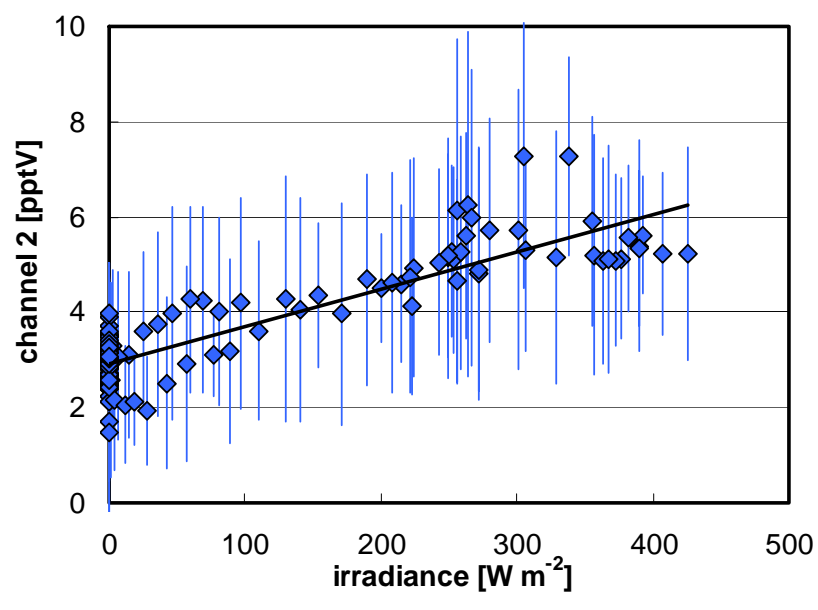

Fig. 6. Plot of the average diurnal $10 \mathrm{~min}$ interference data from channel 2 against the irradiance during the campaign at the Jungfraujoch.

instrument and an LIF instrument, observed in a recent campaign at the South Pole (Liao et al., 2006). Both observations are in excellent agreement with the observed inverse dependency of relative interferences on the pollution level (see Fig. 5), and demonstrate the necessity to verify recently published HONO data from polar regions by instruments free of artefacts.

Acknowledgements. The financial support by the Deutsche Forschungsgemeinschaft (DFG) under Contract No. Wi 958/14-1 within the priority program "Antarctic Research (SPP 1158)" is gratefully acknowledged. In addition, we are grateful to the Deutsche Bundesstiftung Umwelt (DBU), Contract No. 19142 for the financial support during the development of the HONO instrument and to QUMA Elektronik \& Analytik GmbH for their continuous technical support. We also like to thank the International Foundation High Altitude Research Stations Jungfraujoch and Gornergrat (HFSJG), 3012 Bern, Switzerland, for the possibility to carry out our experiments at the Jungfraujoch. In addition, the authors are indebted to Mrs. Willson for her generous help during the organisation of the field campaign. JK also likes to thank Mrs. and Mr. Hemund for the technical help and familial accommodation at the research station Jungfraujoch. In addition, we thank MeteoSwiss, the Swiss Atmospheric Radiation Monitoring program (CHARM) of MeteoSwiss and Vuilleumier for providing the meteorological and irradiance data, respectively. BUWAL/NABEL, Steinbacher and Hüglin are acknowledged for providing the $\mathrm{NO}_{\mathrm{x}}, \mathrm{NO}_{\mathrm{y}}$ and ozone data. Finally, DuPont is gratefully acknowledged for the license agreement for the scientific use of the Teflon AF.

Edited by: A. Pszenny

\section{References}

Acker, K., Möller, D., Wieprecht, W., Meixner, F. X., Bohn, B., Gilge, S., Plass-Dülmer, C., and Berresheim, H.: Strong Daytime Production of $\mathrm{OH}$ from $\mathrm{HNO}_{2}$ at a Rural Mountain Site, Geophys. Res. Lett., 33, L02809, doi:10.1029/2005GL024643, 2006a.

Acker, K., Febo, A., Trick, S., Perrino, C., Bruno, P., Wiesen, P., Möller, D., Wieprecht, W., Auel, R., Guisto, M., Geyer, A., Platt, U., and Allegrini, I.: Nitrous Acid in the Urban Area of Rome, Atmos. Environ., 40, 3123-3133, 2006b.

Alfassi, Z. B., Huie, R. E., and Neta, P.: Substituent Effects on the Rates of One-Electron Oxidation of Phenols by the Radicals $\mathrm{ClO}_{2}, \mathrm{NO}_{2}$, and $\mathrm{SO}_{3}^{-}$, J. Phys. Chem., 90, 4156-4158, 1986.

Ammann, M., Rössler, E., Strekowski, R., and George, C.: Nitrogen Dioxide Multiphase Chemistry: Uptake Kinetics on Aqueous Solutions Containing Phenolic Compounds, Phys. Chem. Chem. Phys., 7, 2513-2518, 2005.

Amoroso, A., Beine, H. J., Sparapani, R., Nardino, M., and Allegrini, I.: Observation of Coinciding Artic Boundary Layer Ozone Depletion and Snow Surface Emissions of Nitrous Acid, Atmos. Environ., 40, 1949-1956, 2006.

Appel, B. R., Winer, A. M., Tokiwa, Y., and Biermann, H. W.: Comparison of Atmospheric Nitrous Acid Measurements by Annular Denuder and Optical Absorption Systems, Atmos. Environ., 24A, 611-616, 1990.

Beine, H. J., Allegrini, I., Sparapani, R., Ianniello, A., and Valentini, F.: Three Years of Springtime Trace Gas and Particle Measurements at Ny-Ålesund, Svalbard, Atmos. Environ., 35, 36453658, 2001.

Beine H. J., Dominé, F., Simpson, W., Honrath, R. E., Sparapani, R., Zhou, X., and King, M.: Snow-pile and Chamber Experiments during the Polar Sunrise Experiment, Alert 2000: Exploration of Nitrogen Chemistry, Atmos. Environ., 36, 2707-2719, 2002.

Beine, H. J., Amoroso, A., Esposito, G., Sparapani, R., Ianniello, A., Georgiadis, T., Nardino, M., Bonasoni, P., Cristofanelli, P., and Dominé, F.: Deposition of Atmospheric Nitrous Acid on Alkaline Snow Surfaces, Geophys. Res. Lett., 32, L10808, doi:10.1029/2005GL022589, 2005.

Beine, H. J., Amoroso, A., Dominé, F., King, M. D., Nardino, M., Ianniello, A., and France, J. L.: Surprisingly small HONO Emissions from Snow Surfaces at Browning Pass, Antarctica, Atmos. Chem. Phys., 6, 2569-2580, 2006,

http://www.atmos-chem-phys.net/6/2569/2006/.

Bloss, W., Lee, J., Heard, D., Salmon, R., Bauguitte, S., and Jones, A.: Box model studies of radical levels during the CHABLIS campaign at Halley Base, Antarctica, EGU General Assemply, Vienna, April 2006, Geophys. Res. Abstr., 6, 03328, 2006.

Bröske, R., Kleffmann, J., and Wiesen, P.: Heterogeneous conversion of $\mathrm{NO}_{2}$ on secondary organic aerosol surfaces: A possible source of nitrous acid (HONO) in the atmosphere?, Atmos. Chem. Phys., 3, 469-474, 2003, http://www.atmos-chem-phys.net/3/469/2003/.

Calvert, J. G., Yarwood, G., and Dunker, A. M.: An Evaluation of the Mechanism of Nitrous Acid Formation in the Urban Atmosphere, Res. Chem. Intermed., 20, 463-502, 1994.

Chen, G., Davis, D., Crawford, J., Hutterli, L. M., Huey, L. G., Slusher, D., Mauldin, L., Eisele, F., Tanner, D., Dibb, J., Buhr, M., McConnel, J., Lefer, B., Shetter, R., Blake, D., Song, C. H., 
Lombardi, K., and Arnoldy, J.: A Reassessment of $\mathrm{HO}_{\mathrm{x}}$ South Pole Chemistry based on Observations Recorded During ISCAT 2000, Atmos. Environ., 38, 5451-5461, 2004.

Clemitshaw, K. C.: Coupling between the Tropospheric Photochemistry of Nitrous Acid (HONO) and Nitric Acid $\left(\mathrm{HNO}_{3}\right)$, Environ. Chem., 3, 31-34, doi:10.1071/EN05073, 2006.

Coe, H., Jones, R. L., Colin, R., Carleer, M., Harrison, R. M., Peak, J., Plane, J. M. C., Smith, N., Allan, B., Clemitshaw, K. C., Burgess, R. A., Platt, U., Etzkorn, T., Stutz, J., Pommereau, J.-P., Goutail, F., Nunes-Pinharanda, M., Simon, P., Hermans, C., and Vandaele, A.-C.: A Comparison of Differential Optical Absorption Spectrometers for Measurement of $\mathrm{NO}_{2}, \mathrm{O}_{3}, \mathrm{SO}_{2}$ and HONO, in: Proceedings of EUROTRAC Symposium'96: Transport and Transformation of Pollutants, edited by: Borrell, P. M., Borrell, P., Cvitaš, T., Kelly, K., Seiler, W., Computational Mechanics Publications, Southampton, ISBN 1-85312-498-2, 757$762,1997$.

Coombes, R. G., Diggle, A. W., and Kempsell, S. P.: The Mechanism of Nitration of Phenol and 4-Methylphenol by Nitrogen Dioxide in Solution, Tetrahedron Lett., 34, 6373-6376, 1994.

Cotter, E. S. N., Jones, A. E., Wolff, E. W., and Bauguitte, S. J.B.: What controls photochemical $\mathrm{NO}$ and $\mathrm{NO}_{2}$ Production from Antarctic Snow? Laboratory Investigation Assessing the Wavelength and Temperature Dependence, J. Geophys. Res., 108(D4), 4147, doi:10.1029/2002JD002602, 2003.

Dibb, J. E., Arsenault, M., Peterson, M. C., and Honrath, R. E.: Fast Nitrogen Oxide Photochemistry in Summit, Greenland Snow, Atmos. Environ., 36, 2501-2511, 2002.

Dibb, J. E., Huey, L. G., Slusher, D. L., and Tanner, D. J.: Soluble Reactive Nitrogen Oxides at South Pole During ISCAT 2000, Atmos. Environ., 38, 5399-5409, 2004.

Dubowski, Y., Colussi, A. J., Boxe, C., and Hoffmann, M. R.: Monotonic Increase of Nitrite Yields in the Photolysis of Nitrate in Ice and Water between 238 and 294 K, J. Phys. Chem. A, 106, 6967-6971, 2002.

Ferm, M. and Sjödin, A.: A Sodium Carbonate Denuder for the Determination of Nitrous Acid in the Atmosphere, Atmos. Environ., 19, 979-983, 1985.

Finlayson-Pitts, B. J., Wingen, L. M., Sumner, A. L., Syomin, D., and Ramazan, K. A.: The Heterogeneous Hydrolysis of $\mathrm{NO}_{2}$ in Laboratory Systems and in Outdoor and Indoor Atmospheres: An Integrated Mechanism, Phys. Chem. Chem. Phys., 5, 223242, 2003.

Frenzel, A., Kutsuna, S., Takeuchi, K., and Ibusuki, T.: Solubility and Reactivity of Peroxyacetyl Nitrate (PAN) in Dilute Aqueous Solutions and in Sulphuric Acid, Atmos. Environ., 34, 36413644, 2000.

Genfa, Z., Slanina, S., Boring, C. B., Jongejan, P. A. C., and Dasgupta, K.: Continuous Wet Denuder Measurements of Atmospheric Nitric and Nitrous Acid During the 1999 Atlanta Supersite, Atmos. Environ., 37, 1351-1364, 2003.

George, C., Strekowski, R. S., Kleffmann, J., Stemmler, K., and Ammann, M.: Photoenhanced Uptake of Gaseous $\mathrm{NO}_{2}$ on Solid Organic Compounds: A Photochemical Source of HONO, Faraday Discuss., 130, 195-210, doi:10.1039/b417888m, 2005.

Grannas, A. M., Shepson, P. B., and Filley, T. R.: Photochemistry and Nature of Organic Matter in Artic and Antarctic Snow, Global Biogeochem. Cy., 18, GB1006, doi:10.1029/2003GB002133, 2004.
Grannas, A. M., Jones, A. E., Dibb, J., Ammann, M., Anastasio, C., Beine, H. J., Bergin, M., Bottenheim, J., Boxe, C. S., Carver, G., Chen, G., Crawford, J. H., Dominé, F., Frey, M. M., Guzmán, M. I., Heard, D. E., Helmig, D., Hoffmann, M. R., Honrath, R. E., Huey, L. G., Hutterli, M., Jacobi, H. W., Klán, P., Lefer, B., McConnell, J., Plane, J., Sander, R., Savarino, J., Shepson, P. B., Simpson, W. R., Sodeau, J. R., von Glasow, R., Weller, R., Wolff, E. W., and Zhu, T.: An overview of snow photochemistry: evidence, mechanisms and impacts, Atmos. Chem. Phys., 7, 4329-4373, 2007,

http://www.atmos-chem-phys.net/7/4329/2007/.

Grasshoff, K., Ehrhardt, M., and Kremling, K.: Methods of Seawater Analysis. 2nd ed., Verlag Chemie: Weinheim, 139-142, 1983.

Gutzwiller, L., Arens, F., Baltensperger, U., Gäggeler, H. W., and Ammann, M.: Significance of Semivolatile Diesel Exhaust Organics for Secondary HONO Formation, Environ. Sci. Technol., 36, 677-682, 2002.

Harris, G. W., Carter, W. P. L., Winer, A. M., Pitts, J. N. Jr., Platt, U., and Perner, D.: Observation of Nitrous Acid in the Los Angeles Atmosphere and Implications for Predictions of Ozone-Precursor Relationships, Environ. Sci. Technol., 16, 414-419, 1982.

Harrison, R. M., Peak, J. D., and Collins, G. M.: Tropospheric Cycle of Nitrous Acid, J. Geophys. Res., 101, 14 429-14 439, 1996.

Heland, J., Kleffmann, J., Kurtenbach, R., and Wiesen, P.: A New Instrument to Measure Gaseous Nitrous Acid (HONO) in the Atmosphere, Environ. Sci. Technol., 35, 3207-3212, 2001.

Honrath, R. E., Peterson, M. C., Guo, S., Dibb, J. E., Shepson, P. B., and Campbell, B.: Evidence of $\mathrm{NO}_{\mathrm{X}}$ Production within or upon Ice Particles in the Greenland Snowpack, Geophys. Res. Lett., 26, 695-698, 1999.

Honrath, R. E., Lu, Y., Peterson, M. C., Dibb, J. E., Arsenault, M. A., Cullen, N. J., and Steffen, K.: Vertical Fluxes of $\mathrm{NO}_{\mathrm{x}}$, $\mathrm{HONO}$, and $\mathrm{HNO}_{3}$ above the Snowpack at Summit, Greenland, Atmos. Environ., 36, 2629-2640, 2002.

Huang, G., Zhou, X., Deng, G., Qiao, H., and Civerolo, K.: Measurements of Atmospheric Nitrous Acid and Nitric Acid, Atmos. Environ., 36, 2225-2235, 2002.

Jacobi, H.-W., Bales, R. C., Honrath, R. E., Peterson, M. C., Dibb, J. E., Swanson, A. L., and Albert, M. R.: Reactive Trace Gases Measured in the Interstitial Air of Surface Snow at Summit, Greenland, Atmos. Environ., 38, 1687-1697, 2004.

Jacobi, H.-W. and Hilker, B.: A Mechanism for the Photochemical Transformation of Nitrate in Snow, J. Photochem. Photobiol. A: Chem., 185, 371-382, 2007.

Jones, A. E., Wolff, E. W., Ames, D., Bauguitte, S. J.-B., Clemitshaw, K. C., Fleming, Z., Mills, G. P., Saiz-Lopez, A., Salmon, R. A., Sturges, W. T., and Worton, D. R.: The multi-seasonal $\mathrm{NO}_{\mathrm{y}}$ budget in coastal Antarctica and its link with surface snow and ice core nitrate: results from the CHABLIS campaign, Atmos. Chem. Phys. Discuss., 7, 4127-4163, 2007, http://www.atmos-chem-phys-discuss.net/7/4127/2007/.

Kanda, Y. and Taira, M.: Chemiluminescent Method for Continuous Monitoring of Nitrous Acid in Ambient Air, Anal. Chem., 62, 2084-2087, 1990.

Keene, W. C., Lobert, J. M., Crutzen, P. J., Maben, J. R., Scharffe, D. H., Landmann, T., Hély, C., and Brain, C.: Emissions of Major Gaseous and Particulate Species during Experimental Burns of Southern African Biomass, J. Geophys. Res., 111, D04301, 
doi:10.1029/2005JD006319, 2006.

Kleffmann, J., Becker, K. H., and Wiesen, P.: Heterogeneous $\mathrm{NO}_{2}$ Conversion Processes on Acid Surfaces: Possible Atmospheric Implications, Atmos. Environ., 32, 2721-2729, 1998.

Kleffmann, J., Heland, J., Kurtenbach, R., Lörzer, J. C., and Wiesen, P.: A new instrument (LOPAP) for the detection of nitrous acid (HONO), Environ. Sci. Pollut. Res., 9 (special issue 4), 48-54, 2002.

Kleffmann, J., Gavriloaiei, T., Hofzumahaus, A., Holland, F., Koppmann, R., Rupp, L., Schlosser, E., Siese, M., and Wahner, A.: Daytime Formation of Nitrous Acid: A Major Source of OH Radicals in a Forest, Geophys. Res. Lett., 32, L05818, doi:10.1029/2005GL022524, 2005.

Kleffmann, J., Lörzer, J. C., Wiesen, P., Kern, C., Trick, S., Volkamer, R., Rodenas, M., and Wirtz, K.: Intercomparisons of the DOAS and LOPAP Techniques for the Detection of Nitrous Acid (HONO) in the Atmosphere, Atmos. Environ., 40, 3640-3652, 2006.

Kleffmann, J.: Daytime Sources of Nitrous Acid (HONO) in the Atmospheric Boundary Layer, Chem. Phys. Chem., 8, 1137-1144, 2007a.

Kleffmann, J., Gavriloaiei, T., Elshorbany, Y., Ródenas, M., and Wiesen, P.: Detection of Nitric Acid $\left(\mathrm{HNO}_{3}\right)$ in the Atmosphere using the LOPAP Technique, J. Atmos. Chem., 58(2), 131-150, $2007 b$.

Li, S.-M: Equilibrium of Particle Nitrite with Gas Phase HONO: Tropospheric Measurements in the High Arctic During Polar Sunrise, J. Geophys. Res., 99, 25 469-25 478, 1994.

Liao, W., Case, A. T., Mastromarino, J., Tan, D., and Dibb, J. E.: Observations of HONO by Laser-Induced Fluorescense at the South Pole during ANTCI 2003, Geophys. Res. Lett., 33, L09810, doi:10.1029/2005GL025470, 2006.

Littlejohn, D., Wang, Y., and Chang, S.-G.: Oxidation of Aqueous Sulfite Ion by Nitrogen Dioxide, Environ. Sci. Technol., 27, 2162-2167, 1993.

Müller, T., Dubois, R., Spindler, G., Brüggemann, E., Ackermann, R., Geyer, A., and Platt, U.: Measurements of Nitrous Acid by DOAS and Diffusion Denuders: A Comparison, in: Proceedings of EUROTRAC Symposium'98: Transport and Chemical Transformation in the Troposphere, Volume I, edited by: Borrell, P. M., Borrell, P., WITPress, Southampton, ISBN 1-85312-743-4, 345-349, 1999.

Neftel, A., Blatter, A., Hesterberg, R., and Staffelbach, T.: Measurement of Concentration Gradients of $\mathrm{HNO}_{2}$ and $\mathrm{HNO}_{3}$ over a Semi-Natural Ecosystem, Atmos. Environ., 30, 3017-3025, 1996.

Platt, U., Perner, D., Harris, G. W., Winer, A. M., and Pitts Jr., J. N.: Observation of Nitrous Acid in an Urban Atmosphere by Differential Optical Absorption, Nature, 285, 312-314, 1980.

Saltzman, B. E.: Colorimetric Microdetermination of Nitrogen Dioxide in the Atmosphere, Anal. Chem., 26, 1949-1955, 1954.

Sjostedt, S. J., Huey, L. G., Tanner, D. J., Peischl, J., Chen, G., Dibb, J. E., Lefer, B., Hutterli, M. A., Beyersdorf, A. J., Blake, N. J., and Blake, D. R.: Peroxy and Hydroxyl Radical Measurements During the Spring 2004 Summit Field Campaign, Eos Trans. AGU, 86(56), Fall Meet. Suppl., Abstract A24A-02, 2005.

Sjostedt, S. J., Huey, L. G., Tanner, D. J., Peischl, J., Chen, G., Dibb, J. E., Lefer, B., Hutterli, M. A., Beyersdorf, A. J., Blake, N. J., Blake, D. R., Sueper, D., Ryerson, T., Burkhart, J., and Stohl,
A.: Observations of Hydroxyl and the Sum of Peroxy Radicals at Summit, Greenland during Summer 2003, Atmos. Environ., 41, 5122-5137, 2007.

Spindler, G., Hesper, J., Brüggemann, E., Dubois, R., Müller, T., and Herrmann, H.: Wet Annular Denuder Measurements of Nitrous Acid: Laboratory Study of the Artefact Reaction of $\mathrm{NO}_{2}$ with S(IV) in Aqueous Solutions and Comparison with Field Measurements, Atmos. Environ., 37, 2643-2662, 2003.

Staffelbach, T., Neftel, A., and Horowitz, L. W.: Photochemical Oxidant Formation Over Southern Switzerland 2. Model Results, J. Geophys. Res., 102, 23 363-23 373, 1997.

Stemmler, K., Ammann, M., Dondors, C., Kleffmann, J., and George, C.: Photosensitized Reduction of Nitrogen Dioxide on Humic Acid as a Source of Nitrous Acid, Nature, 440(7081), doi:10.1038/nature04603, 195-198, 2006.

Stemmler, K., Ndour, M., Elshorbany, Y., Kleffmann, J., D’Anna, B., George, C., Bohn, B., and Ammann, M.: Light induced conversion of nitrogen dioxide into nitrous acid on submicron humic acid aerosol, Atmos. Chem. Phys., 7, 4237-4248, 2007, http://www.atmos-chem-phys.net/7/4237/2007/.

Večeřa, Z. and Dasgupta, P. K.: Measurement of Atmospheric Nitric and Nitrous Acid with a Wet Effluent Diffusion Denuder and Low-Pressure Ion Chromatography-Postcolumn Reaction Detection, Anal. Chem., 63, 2210-2216, 1991.

Vogel, B., Vogel, H., Kleffmann, J., and Kurtenbach, R.: Measured and Simulated Vertical Profiles of Nitrous Acid, Part II - Model Simulations and Indications for a Photolytic Source, Atmos. Environ, 37, 2957-2966, 2003.

Volkamer, R., Sheehy, P. M., Molina, L. T., and Molina, M. J.: Oxidative capacity of the Mexico City atmosphere - Part 1: A radical source perspective, Atmos. Chem. Phys. Discuss., 7, 53655412, 2007, http://www.atmos-chem-phys-discuss.net/7/5365/2007/.

Wiesen, P.: Final Report to the European Framework V Project: Nitrous Acid and its Influence on the Oxidation Capacity of the Atmosphere (NITROCAT), Contract number: EVK2-CT-199900025, Wuppertal, 2002.

Yang, J., Honrath, R. E., Peterson, M. C., Dibb, J. E., Sumner, A. L., Shepson, P. B., Frey, M., Jacobi, H.-W., Swanson, A., and Blake, N.: Impacts of Snowpack Emissions on Deduced Levels of $\mathrm{OH}$ and Peroxy Radicals at Summit, Greenland, Atmos. Environ., 36, 2523-2534, 2002.

Zellweger, C., Forrer, J., Hofer, P., Nyeki, S., Schwarzenbach, B., Weingartner, E., Ammann, M., and Baltensperger, U.: Partitioning of reactive nitrogen $\left(\mathrm{NO}_{\mathrm{y}}\right)$ and dependence on meteorological conditions in the lower free troposphere, Atmos. Chem. Phys., 3, 779-796, 2003, http://www.atmos-chem-phys.net/3/779/2003/.

Zhou, X., Qiao, H., Deng, G., and Civerolo, K.: A Methode for the Measurement of Atmospheric HONO Based on the DNPH Derivatisation and HPLC Analaysis, Environ. Sci. Technol., 33, 3672-3679, 1999.

Zhou, X., Beine, H. J., Honrath, R. E., Fuentes, J. D., Simpson, W., Shepson, P. B., and Bottenheim, J. W.: Snowpack Photochemical Production of HONO: a Major Source of $\mathrm{OH}$ in the Arctic Boundary Layer in Springtime, Geophys. Res. Lett., 28, 40874090, 2001. 
Zhou, X., He, Y., Huang, G., Thornberry, T. D., Cartoll, M. A., and Bertman, S. B.: Photochemical Production of Nitrous Acid on Glass Sample Manifold Surfaces, Geophys. Res. Lett., 29(14), 1681, doi:10.1029/2002GL15080, 2002.
Zhou, X., Huang, G., Civerolo, K., Royxgowdhury, U., and Demerjian, K. L.: Summertime Observations of HONO, HCHO, and $\mathrm{O}_{3}$ at the Summit of Whiteface Mountain, New York, J. Geophys. Res., 112, D08311, doi:10.1029/2006JD007256, 2007. 